\title{
Pengembangan Kompetensi Pelayanan Publik ASN melalui Jalur Magang di Kabupaten Karawang
}

\author{
Rahman Tanjung \\ BKPSDM Kabupaten Karawang, Indonesia \\ E-mail: rahmantanjung1981@gmail.com
}

\section{Article Info \\ Article History \\ Received: 2022-02-03 \\ Revised: 2022-02-22 \\ Published: 2022-03-01}

Keywords:

Competence;

ASN;

Apprenticeship.

\begin{abstract}
The focus of this research is to see how ASN public service competencies improve along the apprenticeship route in Karawang Regency. A qualitative technique was applied in the research. Observation, questionnaires, interviews, and documentation studies were used to gather data. The findings of the data analysis suggest that one of the things that the community emphasizes is public service, because there is a popular assumption that public services provided by civil employees are difficult, convoluted, and inefficient. As a result, in order to improve public services, employees who supply these services, particularly in the sphere of public services, must be prepared with satisfactory performance. Essentially, an ASN must have appropriate competence, as required by Regulations 5 and 23 of 2014. One of the elements of managerial competence that a civil servant must possess is public service. Similarly, one of the government's slogans or employer branding for ASN is "Proud to Serve the Nation," which requires ASN or PNS to be able to give the best public services to the community.
\end{abstract}

Artikel Info
Sejarah Artikel
Diterima: $2022-02-03$
Direvisi: $2022-02-22$
Dipublikasi: $2022-03-01$

Kata kunci:

Kompetensi;

ASN;

Magang.

\begin{abstract}
Abstrak
Penelitian ini bertujuan untuk mengetahui pengembangan kompetensi pelayanan publik ASN melalui jalur magang di Kabupaten Karawang. Metode penelitian yang digunakan dengan pendekatan kualitatif. Pengumpulan data dilakukan dengan menggunakan teknik observasi, angket, wawancara, dan studi dokumentasi. Hasil analisis data menunjukkan bahwa pelayanan publik merupakan salah satu hal yang banyak disorot oleh masyarakat, karena sering ada imej bahwa pelayanan publik yang dikelola oleh PNS ribet, berbelit-belit dan tidak efisien. Oleh karena itu, agar pelayanan publik dapat ditingkatkan, maka pegawai yang memberikan pelayanan tersebut perlu dibekali kompetensi yang cukup, khususnya di bidang pelayanan public. Pada dasarnya seorang ASN harus memiliki kompetensi yang cukup sebagaimana diamanatkan dalam UU Nomor 5 Tahun 2014 dan UU Nomor 23 Tahun 2014. Pelayanan public merupakan salah satu unsur yang ada dalam kompetensi manajerial yang harus dimiliki oleh seorang PNS. Bahkan salah satu slogan atau employer branding ASN yang telah ditetapkan oleh pemerintah adalah "Bangga Melayani Bangsa", dimana ASN atau PNS dituntut untuk dapat memberikan pelayanan publik yang terbaik kepada masyarakat.
\end{abstract}

\section{PENDAHULUAN}

Aparatur Sipil Negara (ASN) saat ini dituntut untuk lebih profesional dalam melaksanakan pekerjaannya yang juga didasari oleh kompetensi dibidangnya masing-masing, seiring dengan agenda reformasi birokrasi yang telah dicanangkan oleh Pemerintah, bahkan sampai dengan saat ini telah banyak metode dalam mengukur kinerja ASN yang dikeluarkan oleh Pemerintah Pusat, mulai dari Sasaran Kinerja Pegawai (SKP) sampai dengan pengukuran profesionalitas pegawai melalui Indeks Profesionalitas Aparatur Sipil Negara, dalam mengukur Profesional tersebut, dapat dilihat melalui kompetensi dalam melaksankan tugas pokok dan fungsi (Tupoksi), kompetensi dalam memberikan pelayanan publik, serta tingginya nilai integritas dan kejujuran yang dimiliki.
Dalam mewujudkan profesionalitas pada ASN tersebut, perlu adanya dukungan melalui kebijakan-kebijakan yang terencana dan terarah dalam tahapan-tahapan pengelolaan kepegawaian, khususnya dalam pengembangan kompetensi pegawai, menurut (Arifudin, 2018) bahwa pengembangan kompetensi atau keahlian karyawan dapat mendorong profesionalitas karyawan. Peningkatkan profesionalisme ASN bisa diwujudkan melalui pengembangan kompetensi, dalam pengembangan kompetensi ASN dimaksud, khususnya Pegawai Negeri Sipil (PNS), secara umum kita mungkin hanya mengenal dalam bentuk kegiatan pelatihan saja, seperti diklat, bimbingan teknis, seminar dan workshop (konsep pembelajaran dalam kelas). Namun sebenarnya pengembangan kompetensi ASN tidak hanya itu saja, menurut Peraturan Lembaga 
Administrasi Negara (LAN) RI Nomor 10 Tahun 2018 tentang Pengembangan Kompetensi PNS, bahwa pengembangan kompetensi dapat dilakukan melalui kegiatan yang menekankan pada proses pembelajaran praktik kerja dan/atau pembelajaran di luar kelas, sehingga dengan hal tersebut, cukup banyak pilihan metode yang dapat digunakan dalam mengembangkan kompetensi PNS, sehingga tidak terlalu terpaku pada kegiatan diklat semata.

Salah satu pengembangan kompetensi PNS yakni magang, kata Magang biasanya identik dengan dunia Pendidikan dan dunia ketenagakerjaan, menurut (Febrianty, 2020) bahwa magang adalah suatu proses mempraktikkan pengetahuan dan keterampilan dengan langsung bersentuhan dengan pelaksanaan kegiatan. Dalam Undang-undang Nomor 13 Tahun 2003 tentang Ketenagakerjaan, pemagangan adalah bagian dari sistem pelatihan kerja yang diselenggarakan secara terpadu antara pelatihan kerja di lembaga pelatihan dengan bekerja secara langsung dibawah bimbingan dan pengawasan instruktur atau pekerja/buruh yang lebih berpengalaman, dalam proses produksi barang dan/atau jasa di perusahaan, dalam rangka menguasai keterampilan atau keahlian tertentu.

Dalam pengembangan kompetensi ASN, kegiatan magang atau praktik kerja sebagaimana diatur dalam Peraturan LAN RI Nomor 10 Tahun 2018 dideskripsikan sebagai Proses pembelajaran untuk memperoleh dan menguasai keterampilan dengan melibatkan diri dalam proses pekerjaan tanpa atau dengan petunjuk orang yang sudah terampil dalam pekerjaan itu (learning by doing). Bagi seorang Aparatur Sipil Negara Kompetensi dapat disikapi dengan hal berbeda. Mereka yang peduli dengan konsep rencana karier (carrier planning) yang jelas, kompetensi merupakan sarana untuk memperoleh jenjang karier dengan adil dan transparan, namun bagi mereka yang mempunyai prinsip hidup "seperti air yang mengalir", maka kompetensi mungkin hanya akan menjadi kata yang tak bermakna.

Menurut (Arifudin, 2021) bahwa kompetensi merupakan seperangkat kemampuan dalam diri seseorang dalam menjalankan tugasnya, secara umum Kompetensi didefinsikan sebagai kemampuan berupa pengetahuan, keterampilan, kecakapan, sikap dan perilaku yang diperlukan dalam pelaksanaan tugas pokok, fungsi kewenangan dan tanggungjawab yang diamanatkan kepadanya. Berdasarkan pasal 69 ayat (3) dalam UU Nomor 5 Tahun 2014 tentang Aparatur Sipil Negara (ASN), ada tiga kompetensi yang harus dimiliki oleh seorang PNS, yaitu: Kompetensi Teknis, Manajerial dan Sosio-kultural. Kompetensi sebagaimana dimaksud ayat (1) meliputi: 1) Kompetensi teknis yang diukur dari tingkat dan spesialisasi pendidikan, pelatihan teknis fungsional, dan pengalaman bekerja secara teknis, 2) Kompetensi manajerial yang diukur dari tingkat pendidikan, pelatihan struktural atau manajemen, dan pengalaman kepemimpinan; dan 3) Kompetensi sosial kultural yang diukur dari pengalaman kerja berkaitan dengan masyarakat majemuk dalam hal agama, suku, dan budaya sehingga memiliki wawasan kebangsaan.

Menurut pasal 233 ayat (2) dalam UU Nomor 23 Tahun 2014 tentang Pemerintahan Daerah, selain ketiga kompetensi tersebut, PNS juga harus memenuhi Kompetensi Pemerintahan. Yang dimaksud dengan "kompetensi pemerintahan" antara lain mencakup pengetahuan, sikap dan keterampilan yang terkait dengan kebijakan Desentralisasi, hubungan Pemerintah Pusat dengan Daerah, pemerintahan umum, pengelolaan keuangan Daerah, Urusan Pemerintahan yang menjadi kewenangan Daerah, hubungan Pemerintah Daerah dengan DPRD dan etika pemerintahan. Mengacu pada peraturanperaturan tersebut menyatakan bahwa seorang ASN atau PNS harus mempunyai beragam kompetensi yang diperlukan dalam melaksanakan tugasnya sebagai seorang abdi negara yang mempunyai kewajiban untuk mencapai kinerja yang optimal demi kemajuan Negara, sejalan dengan hal tersebut, (Tanjung, 2021) menyatakan bahwa dalam mewujudkan PNS yang unggul, profesional dan dinamis, tentunya PNS tersebut tidak bisa apa adanya, harus ada nilai tambah yang dimilikinya. Pengembangan kompetensi ASN sangat perlu untuk terus ditingkatkan dan dikembangkan, karena kondisi kompetensi ASN Indonesia saat ini tidak sepenuhnya baik, hal ini sebagaimana diberitakan dilaman Mediaindonesia.com (2020), bahwa ASN di Indonesia sekitar lebih dari 1,6 juta hanya memiliki kompetensi sebatas administrasi saja, sehingga hal tersebut bisa mengurangi percepatan reformasi birokrasi yang saat ini tengah menjadi fokus pemerintah.

Percepatan reformasi birokrasi yang juga menitikberatkan pada pengembangan kompetensi ASN sangatlah penting, mengingat dalam mewujudkan visi Indonesia 2045, yaitu Indonesia yang berdaulat, maju, adil dan makmur, salah satunya diperlukan Sumberdaya Manusia yang berkualitas dan berdaya saing, hal 
tersebut bisa terealisasi apabila kompetensi ASN Indonesia juga cukup memadai. Tiga aspek penting dari kompetensi yang harus dimiliki oleh ASN meliputi knowledge atau pengetahuan, skill atau keterampilan dan attitude atau sikap, dalam menjalankan tugasnya dalam jabatan sebagai ASN, bahwa berdasarkan Permenpan RB Nomor 20 Tahun 2017 tentang Standar Kompetensi Jabatan ASN, kompetensi yang dibutuhkan ASN meliputi tiga jenis kompetensi, yaitu kompetensi teknis, kompetensi manajerial dan kompetensi sosio kultural. Dengan ketiga kompetensi tersebut, ASN diharapkan bisa menjalankan tugas dan fungsinya dengan baik, terutama yang berkaitan dengan pelayanan terhadap publik atau masyarakat, sebagaimana dituangkan dalam Undang-Undang Nomor 5 Tahun 2014 tentang Manajemen ASN, bahwa salah satu fungsi ASN adalah sebagai pelayan publik yang bertugas memberikan pelayanan pelayanan publik yang profesional dan berkualitas. Pelayanan publik yang berkualitas merupakan bentuk totalitas pelayanan yang dilakukan oleh ASN secara optimal berdasarkan aturan perundangundangan yang berlaku dalam menyediakan pelayanan yang sesuai serta dapat memenuhi kepuasan, kebutuhan dan harapan masyarakat sebagai penerima layanan.

Penyelenggaraan pelayanan publik yang berkualitas, saat ini sudah menjadi tuntutan masyarakat sehingga harus menjadi perhatian pemerintah. Pemerintah telah menyusun produk hukum/peraturan perundang-undangan yang mengatur tentang pelayanan publik untuk menjawab tuntutan masyarakat, sejalan dengan itu untuk penerapan peraturan tersebut, dibutuhkan pemantauan dan pengawasan dari seluruh lapisan masyarakat, agar pelayanan yang sudah punya standar baku dapat diterapkan oleh pemerintah, dimana dampaknya adalah masyarakat dapat menerima pelayan tanpa pilih kasih. Undang-Undang Nomor 25 Tahun 2009 tentang Pelayanan Publik mendefinisikan pelayanan publik sebagai kegiatan atau rangkaian kegiatan dalam rangka pemenuhan kebutuhan pelayanan sesuai dengan peraturan perundang-undangan bagi setiap warga negara dan penduduk atas barang, jasa, dan/atau pelayanan administratif yang disediakan oleh penyelenggara pelayanan publik. Masyarakat sebagai penerima layanan publik pada umumnya pasti menginginkan pelayanan publik yang memuaskan, mudah, murah dan cepat, melalui pengembangan kompetensi ASN di bidang pelayanan, diharapkan dapat mendorong terciptanya pelayanan publik yang prima dan optimal, salah satu bentuk pengembangan kompetensi ASN yang mungkin cukup jarang dilaksanakan adalah dalam bentuk Magang atau praktik kerja pada suatu Lembaga/perusahaan. Hal ini yang kini coba diimplementasikan oleh pemerintah Kabupaten Karawan melalui Badan Pengembangan Kepegawaian dan Sumber Daya Manusia (BKPSDM) Kabupaten Karawang yang bekerjasama dengan PT. Bank BJB Cabang Karawang dalam mengembangkan kompetensi ASN Kabupaten Karawang, khususnya yang bekerja di sektor pelayanan publik.

Banyak studi atau penelitian terkait pengembangan kompetensi ASN, tetapi pada umumnya penelitian-penelitian tersebut hanya membahas tentang kegiatan pengembangan kompetensi ASN secara umum di suatu Pemerintahan Daerah atau hanya membahas pengembangan kompetensi ASN melalui kegiatan Diklat saja dan pengaruhnya terhadap pembentukan perilaku anti-korupsi. Sebagaimana diungkapkan oleh (Fathurrochman, 2017) bahwa pegawai merupakan asset yang cukup penting dalam mencapai tujuan suatu organisasi, sehingga diperlukan pengembangan sumber daya manusia untuk mewujudkannya. Menurut (Kusumaningrum, 2017) menjelaskan bahwa bentuk pengembangan kompetensi terdiri dari dua jalur, yaitu pelatihan klasikal dan pelatihan non-klasikal. Pelatihan klasikal merupakan jalur pelatihan melalui proses pembelajaran tatap muka di dalam kelas, misalnya melalui pelatihan, seminar, kursus dan penataran. Sedangkan jalur pelatihan non klasikal contohnya seperti: elearning, bimbingan di tempat kerja, pelatihan jarak jauh, magang dan pertukaran antara PNS dan pegawai swasta. Selanjutnya dijelaskan juga bahwa praktik pelayanan publik di Indonesia dapat berkaitan dengan masalah yang ikut serta dalam pelaksanaan pelayanan publik tersebut seperti korupsi, tidak transparan, tidak efektif dan efisien, sehingga melalui pengembangan kompetensi pegawai bisa memberikan dampak atas terbentuknya perilaku anti-korupsi di kalangan ASN (Zainuddin, 2020).

Berdasarkan pada ketiga hasil penelitian yang telah dilakukan sebelumnya di atas, belum ada penelitian yang khusus meneliti tentang pengembangan kompetensi ASN di bidang pelayanan publik melalui jalur magang. Magang atau praktik kerja merupakan salah satu bentuk pengembangan kompetensi dalam jalur non klasikal yang bisa diterapkan oleh Pemerintah Daerah yang juga telah diatur oleh peraturan 
perundang-undangan yang berlaku saat ini, yaitu Peraturan LAN RI Nomor 10 Tahun 2018. Adapun tujuan dari penelitian ini adalah untuk menganalisis bagaimana pengembangan kompetensi ASN di Kabupaten Karawang khususnya bagi ASN yang bekerja di sektor pelayanan publik melalui kegiatan magang atau praktik kerja di tempat lain.

\section{METODE PENELITIAN}

Penelitian ini berusaha untuk menganalisis dan mendeskripsikan pengembangan kompetensi pelayanan publik ASN melalui jalur magang di Kabupaten Karawang, jenis penelitian yang digunakan pada penelitian ini adalah berupa metode deskriptif analisis, menurut (Rahayu, 2020) bahwa deskriptif analisis adalah penelaahan secara empiris yang menyelidiki suatu gejala dalam latar kehidupan nyata, hasil penelitian ini dikumpulkan dengan data primer dan data skunder. Adapun pendekatan yang digunakan dalam penelitian ini adalah pendekatan kualitatif, menurut Bogdan dan Taylor dalam (Bahri, 2021) menyatakan pendekatan kualitatif adalah prosedur penelitian yang menghasilkan data deskriptif berupa katakata tertulis atau lisan dari orang-orang dan perilaku yang dapat diamati, caranya dengan mentranskripsikan data, kemudian pengkodean pada catatan-catatan yang ada di lapangan dan diinterpretasikan data tersebut untuk memperoleh kesimpulan. Penentuan teknik pengumpulan data yang tepat sangat me-nentukan kebenaran ilmiah suatu penelitian. Teknik pengumpulan data yang digunakan dalam penelitian ini adalah:

1. Observasi

Observasi adalah bagian dari proses penelitian secara langsung terhadap fenomenafenomena yang hendak diteliti (Hanafiah, 2021), dengan metode ini peneliti dapat melihat dan merasakan secara langsung suasana dan kondisi subyek penelitian, hal-hal yang diamati dalam penelitian ini adalah tentang pengembangan kompetensi pelayanan publik ASN melalui jalur magang di Kabupaten Karawang.

2. Wawancara

Teknik wawancara dalam penelitian ini adalah wawancara terstruktur, yaitu wawancara yang dilakukan dengan menggunakan pedoman yang telah ditetapkan sebelumnya, pertanyaan disusun secara ketat dan pertanyaan sama pada setiap subjek (Sugiyono, 2008).
3. Dokumentasi

Dokumentasi adalah salah satu teknik pengumpulan data melalui dokumen atau catatan-catatan tertulis yang ada (Tanjung, 2019). Dokumentasi berasal dari kata dokumen, yang berarti barang-barang tertulis. Di dalam melaksanakan metode dokumentasi, peneliti menyelidiki benda-benda tertulis, seperti buku-buku, majalah, notula rapat, dan catatan harian, menurut Moleong dalam (Tanjung, 2022) bahwa metode dokumentasi adalah cara pengumpulan informasi atau data-data melalui pengujian arsip dan dokumen-dokumen. Strategi dokumentasi juga merupakan teknik pengumpulan data yang diajukan kepada subyek penelitian, metode pengumpulan data dengan menggunakan metode dokumentasi ini dilakukan untuk mendapatkan data tentang keadaan lembaga (obyek penelitian) yaitu keberadaan pengelolaan pengembangan kompetensi pelayanan publik ASN melalui jalur magang di Kabupaten Karawang, dan keadaan stafnya, menurut Muhadjir dalam (Tanjung, 2020) menyatakan bahwa analisis data merupakan kegiatan melakukan, mencari dan menyusun catatan temuan secara sistematis melalui pengamatan dan wawancara sehingga peneliti fokus terhadap penelitian yang dikajinya. Setelah itu menjadikan sebuah bahan temuan untuk orang lain, mengedit, mengklasifikasi, dan menyajikannya.

\section{HASIL DAN PEMBAHASAN}

Badan Kepegawaian dan Pengembangan Sumber Daya Manusia (BKPSDM) Kabupaten Karawang mempunyai tugas pokok membantu Bupati melaksanakan fungsi penunjang urusan pemerintahan yang menjadi kewenangan daerah bidang kepegawaian dan bidang pendidikan dan pelatihan serta tugas pembantuan yang ditugaskan kepada daerah, salah satu hal yang menjadi perhatian dari Bupati Karawang adalah masalah pelayanan publik, oleh karena itu untuk meningkatkan kapasitas dan kompetensi ASN dalam hal tersebut, BKPSDM Kabupaten Karawang melaksanakan program magang atau praktik kerja. Program ini merupakan salah satu bentuk pengembangan kompetensi dalam bentuk non-klasikal, yaitu dilakukan melalui kegiatan yang menekankan pada proses pembelajaran praktik kerja dan/atau pembelajaran di luar kelas sebagaimana mengacu pada pasal 29 ayat (1) Peraturan LAN RI Nomor 10 Tahun 2018. Tujuan diadakannya program magang bagi 
Pegawai Negeri Sipil di lingkungan Pemerintah Kabupaten Karawang ini adalah untuk meningkatkan pengetahuan, kemampuan dan keterampilan para peserta dalam melaksanakan pelayanan publik, agar kegiatan tersebut dapat berjalan lancar, maka dilakukan dengan menerapkan fungsi-fungsi dalam manajemen secara umum.

Dalam merencanakan kegiatan magang ini, Bidang Diklat mengadakan rapat awal terlebih dahulu dengan mengundang para Widyaiswara dan Sekretaris BKPSDM Kabupaten Karawang pada 8 Februari 2021 untuk menentukan PNS dari instansi mana yang akan menjadi peserta. Dari hasil pertemuan tersebut, disepakati calon peserta kegiatan magang PNS adalah dari instansi yang memberikan pelayanan publik langsung kepada masyarakat, yaitu Dinas Penanaman Modal dan Pelayanan Terpadu Satu Pintu (DPMPTSP), Dinas Kependudukan dan Catatan Sipil (Disdukcatpil) dan Badan Pendapatan Daerah (Bapenda), yang masing-masing instansi diwakili oleh 2 (dua) orang pegawai, selain tentang peserta dalam rapat tersebut telah ditetapkan bahwa lokasi pelaksanaan magang adalah di Bank BJB Cabang Karawang, kegiatan dalam perencanaan lainnya adalah melakukan koordinasi dengan pihak Bank BJB yang dilaksanakan pada tanggal 15 Februari 2021, untuk menetapkan waktu pelaksanaan, serta bentuk dan mekanisme kegiatan magang.

Setelah ditetapkan asal calon peserta magang serta waktu dan tempat pelaksanaan kegiatan magang, selanjutnya dibentuk tim kecil untuk menyusun materi kegiatan magang, yang terdiri dari unsur pejabat struktural Bidang Diklat BKPSDM dan Widyaiswara. Berikutnya, BKPSDM juga berkirim surat ke tiga Instansi dimaksud, untuk meminta nama-nama PNS yang akan menjadi peserta kegiatan magang di Bank BJB.

Berdasarkan usulan dari masing-masing instansi tersebut, maka ditetapkanlah melalui Surat Perintah Kepala BKPSDM Kabupaten Karawang peserta kegiatan magang PNS tahun 2021, yaitu:

Tabel 1. Daftar Nama Peserta Kegiatan Magang PNS

\begin{tabular}{clll}
\hline No & Nama & Pangkat/Gol. & Instansi \\
\hline 1 & Firman & III/c & Bapenda \\
& Umbara, SE & & \\
\hline 2 & $\begin{array}{l}\text { Vallianta SK, } \\
\text { SE }\end{array}$ & III/b & Bapenda \\
\hline 3 & $\begin{array}{l}\text { Moch. Dadan } \\
\text { Juaeni, SH }\end{array}$ & III/c & DPMPTSP \\
\hline 4 & Uum Sumiati, & III/b & DPMPTSP \\
& SH & III/b & Disdukcatpil \\
\hline 5 & Sopyan &
\end{tabular}

\begin{tabular}{|c|c|c|}
\hline & Jamaludin, SE & \\
\hline 6 & $\begin{array}{l}\text { Sofie } \\
\text { Juhaeriah, SE }\end{array}$ & Disdukcatpil \\
\hline
\end{tabular}

Kegiatan magang ini dilaksanakan selama 3 (tiga) hari kerja, dimulai dari tanggal 5 April 2021 sampai dengan 7 April 2021 bertempat di Kantor Bank BJB Cabang Karawang, kegiatan magang dibagi menjadi dua sub kegiatan, yaitu pemberian materi dan praktek, pada hari pertama, kegiatan magang diisi dengan penyampaian materi oleh Widyaiswara dan Bagian Pelayanan Bank BJB terkait Materi Pelayanan Prima. Selanjutnya pada hari kedua dilakukan role play pelayanan dan penanganan keluhan yang dibimbing langsung oleh tim dari Bank BJB, pada hari terakhir kegiatan magang, peserta langsung dilibatkan dalam praktik pelayanan nasabah secara langsung dengan pendampingan dari petugas pelayanan Bank BJB. Berdasarkan hasil wawancara singkat dengan beberapa perwakilan peserta kegiatan magang ini, mereka sangat antusias dalam mengikuti kegiatan tersebut, karena selain mendapatkan pengetahuan baru tentang pemberian pelayanan prima kepada masyarakat, juga dapat merasakan langsung perbedaan pemberian pelayanan antara Pemerintah dan Swasta, sehingga mereka berharap hal-hal yang didapatkan dari kegiatan magang dapat diimplementasikan ketika mereka bertugas di instansinya masing-masing.

Kegiatan pengawasan atau evaluasi dari kegiatan ini belum dilakukan, namun di-rencanakan akan dilakukan evaluasi paling lambat satu tahun setelah kegiatan selesai dilaksanakan, untuk mengukur apakah peserta telah menerapkan pelayanan prima di instansi-nya masingmasing melalui 3 (tiga) metode evaluasi, yaitu: evaluasi kepada peserta, atasan langsung dan rekan sejawat.

\section{SIMPULAN DAN SARAN}

\section{A. Simpulan}

Berdasarkan hasil penelitian dan pembahasan yang telah disajikan maka dapat diambil simpulan bahwa pelayanan publik merupakan salah satu hal yang banyak disorot oleh masyarakat, karena seringa da imej bahwa pelayanan publik yang dikelola oleh PNS ribet, berbelit-belit dan tidak efisien, oleh karena itu, agar pelayanan publik dapat ditingkatkan, maka pegawai yang memberikan pelayanan tersebut perlu dibekali kompetensi yang cukup khususnya di bidang pelayanan publik. Pada dasarnya seorag ASN harus memiliki kompetensi yang cukup 
sebagaimana diamanatkan dalam UU Nomor 5 Tahun 2014 dan UU Nomor 23 Tahun 2014. Pelayanan public merupakan salah satu unsur yang ada dalam kompetensi manajerial yang harus dimiliki oleh seorang PNS, bahkan salah satu slogan atau employer branding ASN yang telah ditetapkan oleh pemerintah adalah "Bangga Melayani Bangsa", dimana ASN atau PNS dituntut untuk dapat memberikan pelayanan publik yang terbaik kepada masyarakat.

\section{B. Saran}

Adapun saran yang dapat disampaikan berdasarkan hasil simpulan penelitian bahwa kegiatan magang yang digagas oleh BKPSDM Kabupaten Karawang merupakan salah satu metode baru yang jarang dilaksanakan oleh Sebagian besar Pemerintah Daerah dalam mengembangkan kompetensi ASN, kegiatan ini pada dasarnya diharapkan dapat berjalan lebih efektif, karena tidak hanya memberikan teori dan pemahaman tentang pelayanan publik yang prima, tetapi peserta dilatih praktik dan terjun langsung dalam pemberian pelayanan kepada masyarakat dengan dibimbing oleh tenaga profesional dan pengalaman. Hal ini bisa dilakukan oleh pemerintah daerah lain dan dapat di optimalkan dalam pelaksanaannya agar menghasilkan perbaikan dalam rangka mengembankan kompetensi ASN.

\section{DAFTAR RUJUKAN}

Arifudin, O. (2018). Pengaruh Pelatihan Dan Motivasi Terhadap Produktivitas Kerja Tenaga Kependidikan STIT Rakeyan Santang Karawang. MEA (Manajemen, Ekonomi, \& Akuntansi), 2(3), 209-218.

Arifudin, O. (2021). Manajemen Strategik Teori Dan Implementasi. Banyumas: Pena Persada.

Bahri, A. S. (2021). Pengantar Penelitian Pendidikan (Sebuah Tinjauan Teori dan Praktis). Bandung: Widina Bhakti Persada.

Fathurrochman. (2017). Pengembangan Kompetensi Pegawai Aparatur Sipil Negara (ASN) Sekolah Tinggi Agama Islam Negeri (STAIN) Curup Melalui Metode Pendidikan Dan Pelatihan. Manajer Pendidikan, 11(2), 23-30.
Febrianty, F. (2020). Kepemimpinan \& Prilaku Organisasi Konsep Dan Perkembangan. Bandung: Widina Bhakti Persada.

Hanafiah, H. (2021). Pelatihan Software Mendeley Dalam Peningkatan Kualitas Artikel Ilmiah Bagi Mahasiswa. Jurnal Karya Abdi Masyarakat, 5(2), 213-220.

Kusumaningrum. (2017). Pengembangan Kompetensi Aparatur Sipil Negara Di Lingkungan Pemerintah Provinsi Kalimantan Timur. Jurnal Borneo Administrator, 13(2), 131-150.

Peraturan Lembaga Administrasi Negara (LAN) RI Nomor 10 Tahun 2018 tentang Pengembangan Kompetensi PNS

Permenpan RB Nomor 20 Tahun 2017 tentang Standar Kompetensi Jabatan ASN

Rahayu, Y. N. (2020). Program Linier (Teori Dan Aplikasi). Bandung : Widina Bhakti Persada.

Shavab, F. A. (2021). Dasar Manajemen \& Kewirausahaan (Sebuah Tinjauan Teori Dan Praktis). Bandung : Widina Bhakti Persada.

Sugiyono. (2008). Metode Penelitian Bisnis. Bandung : Alfa Beta.

Tanjung, R. (2019). Manajemen Pelayanan Prima Dalam Meningkatkan Kepuasan Mahasiswa Terhadap Layanan Pembelajaran (Studi Kasus di STIT Rakeyan Santang Karawang). Jurnal Ilmiah MEA (Manajemen, Ekonomi, \& Akuntansi), 3(1), 234-242.

Tanjung, R. (2020). Analisis Pengaruh Penilaian Kinerja Dan Kompensasi Terhadap Produktivitas Kerja Pada PDAM Kabupaten Karawang. Jurnal Ilmu Manajemen, 10(1), 71-80.

Tanjung, R. (2021). APA ADANYA ATAUKAH ADA APANYA?

http://rahmantanjung.prajaberdaya.id/arti cle/2021/11/apa-adanya-ataukah-adaapanya-2304630?bima access status=valid

Tanjung, R. (2022). Manajemen Mutu Dalam Penyelenggaraan Pendidikan. Jurnal Pendidikan Glasser, 6(1), 29-36. 
Undang-Undang Nomor 5 Tahun 2014 tentang Manajemen ASN

Undang-Undang Nomor 25 Tahun 2009 tentang Pelayanan Publik

Undang-undang Nomor 13 Tahun 2003 tentang Ketenagakerjaan

Undang-Undang Nomor 5 Tahun 2014 tentang Aparatur Sipil Negara (ASN)
UU Nomor 23 Tahun 2014 tentang Pemerintahan Daerah

Zainuddin. (2020). Pengembangan Kapasitas Pegawai Negeri Sipil Dan Pengaruhnya Terhadap Perilaku Anti Korupsi (Studi Kasus PNS Pemerintah Kota Pontianak). Jurnal Widyaiswara Indonesia, 1(4), 187198. 